\title{
Colombian Nepticuloidea and Tischerioidea: a small step out of obscurity
}

\author{
Jonas R. Stonis ${ }^{1,2^{*}}$, \\ Andrius Remeikis ${ }^{2}$, \\ Sergio A. Vargas ${ }^{3}$ \\ ${ }^{1}$ Vytautas Magnus University, \\ K. Donelaičio St. 58, \\ Kaunas 44248, Lithuania \\ ${ }^{2}$ Nature Research Centre \\ and Baltic-American \\ Biotaxonomy Institute, \\ Akademijos St. 2, \\ Vilnius 08412, Lithuania \\ ${ }^{3} J a r d i n$ Botánico de Bogotá \\ José Celestino Mutis, \\ Av. Calle 63 No. 68-95, \\ Bogotá, Colombia
}

\begin{abstract}
We summarize the results of the fieldwork conducted in southwestern Colombia in 2019 and report on new taxa discovered in Colombia. We provide a description of Stigmella foreroi Stonis \& Vargas, sp. nov., recently discovered in the Valle del Cauca region, and encourage further research into the Colombian fauna.
\end{abstract}

Keywords: Colombian fauna, leaf-mining insects, new species, Nepticulidae, Opostegidae, Tischeriidae

\section{INTRODUCTION}

One of the distinctive features of modern life is its intensity. It also poses ever new and, in a number of cases, existential challenges, be it climate change, global biodiversity crisis, a lack of qualified professionals, or the need for STEM education. Even in the age of technology, social development must be accompanied by the investigation into the structural elements of nature, especially those of economic relevance.

Nowadays we are seriously concerned about the biodiversity crisis. This growing concern stim-

\footnotetext{
* Corresponding author. Email: stonis.biotaxonomy@gmail.com
}

ulates a more active inventory of various biomes of the Earth. Unfortunately, biodiversity is undergoing a very rapid decline due to human economic activity and severe destruction or fragmentation of habitats. In tropical regions, this decline has gained a much greater rate (Stonis, 2010). Biotaxonomists are actually competing against time: many organism species may become extinct and will never be discovered. It is therefore not surprising that there is a popular saying among biotaxonomists, "newly discovered species are the jewel of biodiversity" (Stonis, 2010).

The objects of the study, Nepticuloidea (Nepticulidae and Opostegidae) and Tischerioidea (Tischeriidae), are not common in scientific collections. However, they are among the most 
significant Lepidoptera groups from the theoretical, i.e., evolutionary, point of view. They are also characterized by a highly specialized lifestyle of mining in assimilative tissues of plants (Figs. 1-10, 18, 19). Some of the Nepticulidae and Tischeriidae have already been included in the lists of pests of cultivated plants (Kuznetzov, Puplesis, 1994). Since the occurences of their invasions or epizootic outbreaks are quite likely, they are economically important.

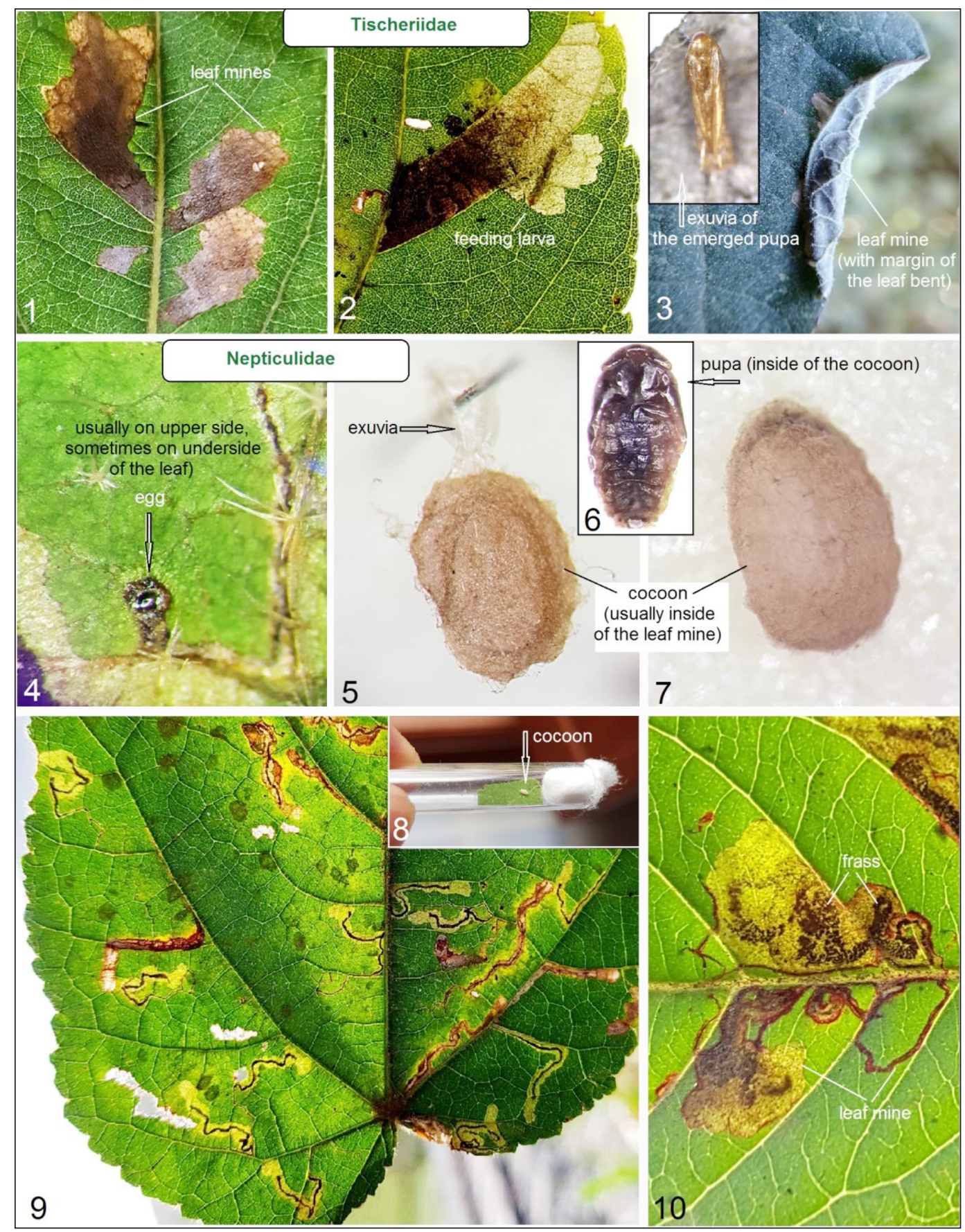

Figs. 1-10. Bionomics of Tischeriidae (Tischerioidea) and Nepticulidae (Nepticuloidea). 1-3 - leaf mines of Tischeriidae; 4 - egg of Nepticulidae on a leaf of the host plant; 5-8 - cocoons and pupa of Nepticulidae from Colombia; 9, 10 - leaf mines of Nepticulidae on Guazuma ulmifolia (9) and Psidium guajava (10) 
We suppose that curent global trade links and the emergence of new tourist routes are bound to significantly increase the danger of the introduction of alien pests (Diškus, Stonis, 2012).

Nepticuloidea and Tischerioidea are widespread and occur practically in all terrestrial habitats, and because of endemism and a high degree of stenophagy of the species these organisms serve as a means for assessing or monitoring biodiversity richness of habitats and provide data on the evolutionary processes (Diškus, Stonis, 2012; Remeikis, 2017).

Being extremely small and leading a hidden lifestyle within plant tissues, these insects still remain insufficiently investigated in many regions. Moreover, it is also compounded by disturbing decline in the number of qualified specialists and painful absence of diagnostic tools for researchers, environmentalists, or specialists in the field of forestry, agriculture, and even of STEM education (both globally and in the countries of Latin America) (Stonis, 2010; Stonis et al., 2015).

Colombia is regarded as one of the world's megadiverse countries hosting close to $10 \%$ of the planet's biodiversity (Colombia - Country Profile, 2015; Colombia - Wildlife Conservation Society, 2015). Meanwhile, until recently the list of the Colombian Nepticuloidea comprised only about $0.5 \%$ of the world's nepticuloid fauna: $0.6 \%$ of Nepticulidae and $0.5 \%$ of the world's Opostegidae (or 1.15\% of the Neotropical Opostegidae) (Stonis et al., 2015, 2016a, 2017a). The situation with Colombia's Tischeriidae (Tischerioidea), a related family (superfamily) to Nepticuloidea, was even worse. Though about 125 species were known globally prior to our study (Stonis et al., submitted), not a single species of these insects from Colombia has been registered. The situation was rather embarrassing and required urgent action, i.e., extensive taxonomic studies of Nepticulidae, Opostegidae, and Tischeriidae in different ecosystems and habitats of Colombia (Stonis et al., 2015). Without such basic data on fauna and ecological characteristics (e.g., trophic relationships and seasonal cycles), it is impossible to efficiently solve problems of the protection of natural regions and continue any further research.
All this motivated us to conduct studies on nepticuloids and tischerioids in Colombia (and South America in general), one of the Earth's richest but still poorly studied regions as regards the leaf-mining insects.

The goal of our study was a taxonomic and trophic study into the Nepticuloidea and Tischerioidea fauna of Colombia: to collect, identify, document the specific leaf-mining fauna, and to define trophic relationships and species which may be relevant as pests (or potential pests) of cultivated or otherwise economically significant plants.

Despite the fact that our most recent study was very limited in time and resources, it yielded some interesting and important results, which we summarize in the current paper.

\section{MATERIALS AND METHODS}

In the course of our fieldwork from February to early March 2019 in Valley del Cauca (Figs. 11-17), we collected some Nepticuloidea and Tischerioidea specimens. All material is deposited in the collection of Laboratorio de Entomología, UNESIS, Departamento de Biología, Pontificia Universidad Javeriana, Bogotá, Colombia (further abbreviated as MPUJ). It was collected by Jonas R. Stonis and Sergio A. Vargas, assisted by Franklin J. Galindo (Collecting Permit No. 2019007511-1-000 by Autoridad Nacional de Licencias Ambientales, Bogotá, Colombia).

The collecting methods are outlined in Puplesis, Robinson (2000), Puplesis, Diškus (2003), and Diškus, Stonis (2012), Stonis et al. (2018a). The material was obtained by rearing adults from mining larvae (Figs. 18, 19) and by attracting adults to mercury-vapour light from a lamp suspended in front of a white screen (light-collecting) (Figs. 20, 21). Rearing adults from larvae enabled us not only to obtain premium quality collection material but also define ecological characteristics of Tischeriidae (Figs. 1-3) and Nepticulidae (Figs. 4-10).

The techniques for genitalia preparation and the protocols for description are outlined in Stonis et al., 2014. After maceration 

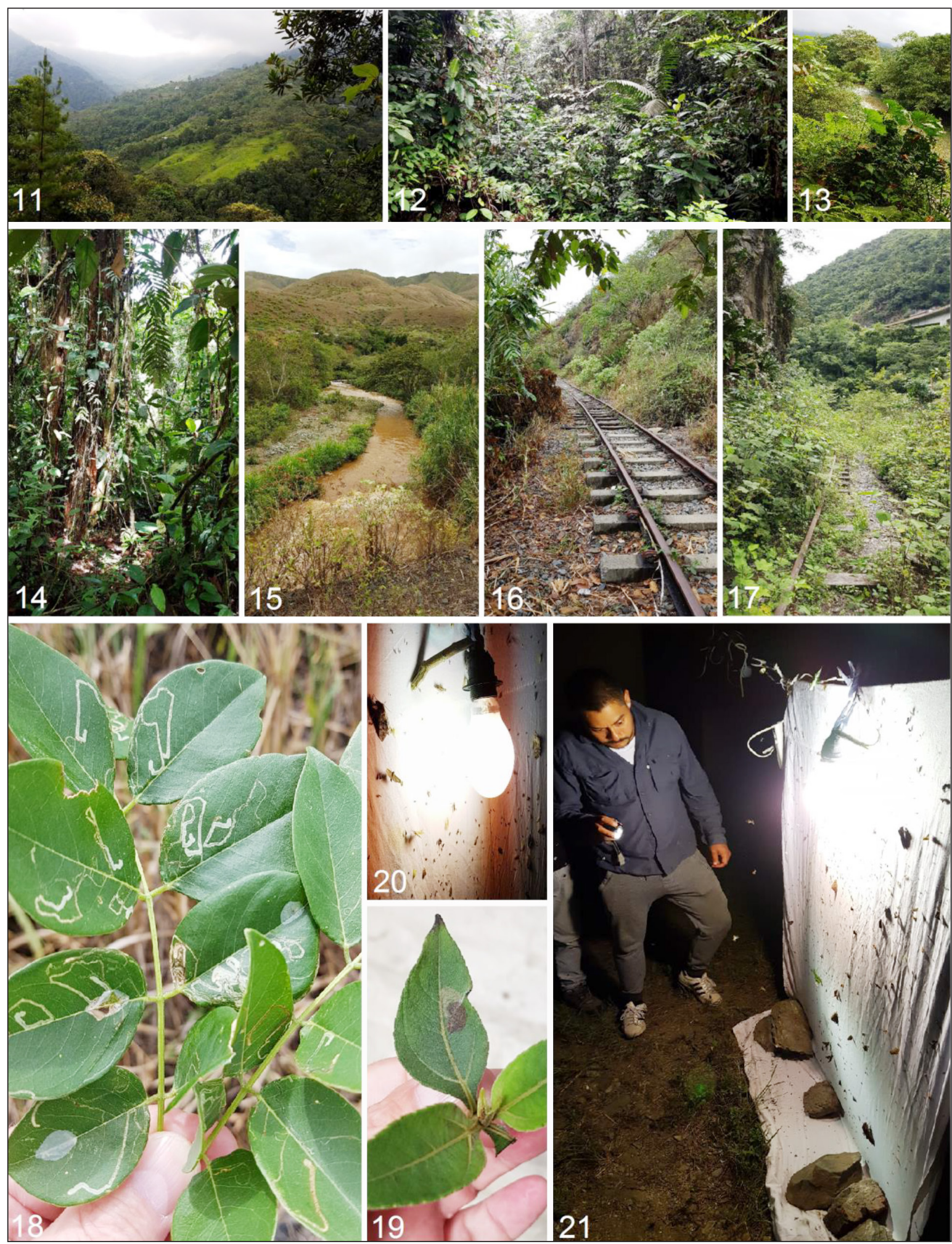

Figs. 11-21. Collecting and habitats covered by our study in Valle del Cauca: 11 - SW of Cali, Vía Villa Carmelo; 12-14 - lowland tropical forest near San Cipriano; 15, 16 - Lobo Guerrero, $850 \mathrm{~m}, 3^{\circ} 45^{\prime} 58^{\prime \prime} \mathrm{N}$, $76^{\circ} 40^{\prime} 43^{\prime \prime} \mathrm{W} ; 17$ - El Naranjo, $550 \mathrm{~m}, 3^{\circ} 46^{\prime} 46^{\prime \prime} \mathrm{N}, 76^{\circ} 43^{\prime} 63^{\prime \prime} \mathrm{W} ; 18$ - numerous leaf mines of Acalyptris, Nepticulidae, on Gliricidia sepium, Fabaceae; 19 - leaf mine of Astrotischeria, Tischeriidae, on an Asteraceae plant; 20, 21 - attracting moths by a mercury-vapour light from a lamp suspended in front of a white screen (21 - Sergio A. Vargas) 
of the abdomen in $10 \% \mathrm{KOH}$ and subsequent cleaning, male genital capsules were removed from the abdomen and mounted ventral side uppermost. The phallus was removed and mounted alongside the genital armature. Abdominal pelts and female genitalia were stained with Chlorazol Black (Direct Black 38/ Azo Black), and mounted in Euparal.

Permanent preparations on microscope slides were photographed and studied using a Leica DM2500 microscope and a Leica DFC420 digital camera. Adults were photographed using a Leica S6D stereoscopic microscope with a Leica DFC290 digital camera attached.

The descriptive terminology of morphological structures follows Johansson et al. (1990) and Puplesis, Robinson (2000) except for the term "aedeagus", which is here referred to as "phallus" and the term "cilia", which is here referred to as "fringe".

Largerly following the most recent biogeographic regionalization provided by Morrone (2014, particularly 2015), we accept the AndoPatagonian biogeographical region (Stonis et al. 2016b, 2017b; Remeikis, 2017) as a separate region from the Neotropical region, including the South American transition zone. However, for convenience we use the term "Neotropics" (sensu lato), covering both the Ando-Patagonian and Neotropical (sensu stricto) regions.

\section{RESULTS}

\section{Description of a new species, Stigmella fore- roi Stonis \& Vargas, sp. nov.}

(Figs. 17, 20-33)

Type material. Holotype: COLOMBIA: $\widehat{\partial}$, Departamento de Valle del Cauca, Municipio de Dagua, El Naranjo, $550 \mathrm{~m}$, at light, $3^{\circ} 46^{\prime} 46^{\prime}$ 'N, 76²3'63"W, 21-23.ii.2019, J. R. Stonis \& S. A. Vargas, genitalia slide no. RA1026 (MPUJ). Paratype: $1 \widehat{\partial}$, same label data as holotype (MPUJ).

Diagnosis. A distinctive species among all congeneric Stigmella because of the peculiar character of the male genitalia: the deep proximal excavation of the ventral plate of vinculum (Fig. 31), thickened inner side of the valva (Fig. 33), elaborated transtilla (Fig. 32), and absence of cornuti in the phallus (Fig. 26). The large, lyra-shaped gnathos (Fig. 28), large uncus with an X-shaped thickening (Fig. 32) in the male genitalia, and the wide white fascia on the black forewing (Figs. 22-25) also make this species distinctive (also see Remarks).

Male (Figs. 29-32). Forewing length: 1.4$1.6 \mathrm{~mm}(n=2)$, wingspan: $3.2-3.6(n=2)$. Head: palpi greyish cream; frontal tuft pale, brownish orange; collar small, concolorous with scape, silvery cream to golden cream, shiny; antenna distinctly shorter than half the length of forewing; flagellum with 19-20 segments, glossy, grey to dark grey on upper side, greyish cream to pale grey on underside. Thorax, tegula and forewing concolorous, brown-black, with purple iridescence particularly prominent in basal half of the forewing; forewing fascia slightly postmedian, wide, comprised of white, silver shiny scales; fringe blackish grey, apically white; underside of forewing entirely grey-black, without androconia, with purple iridescence in basal half. Hindwing blackish grey with little purple iridescence on upper side and underside, with no spots or androconia; its fringe blackish grey. Legs very glossy, greyish cream; hindlegs, except tarsi, covered with black scales. Abdomen glossy, black on upper side, yellowish cream on underside; tufts indistinct or absent; genital segments yellowish cream.

Female. Unknown.

Male genitalia (Figs. 26-33). Capsule about $200 \mu \mathrm{m}$ long, $125 \mu \mathrm{m}$ wide. Uncus very large, with an X-shaped thickening (Fig. 32) and weakly demarcated lateral lobes (Fig. 28). Gnathos very large, lyra-shaped (Fig. 28). Valva with a pointed thickening apically (Figs. 27, 31); inner side with elaborated thickenings (Fig. 33); transtilla with unusual elaboration (Fig. 32). Juxta absent. Phallus (Figs. 26, 29, 30) about $125 \mu \mathrm{m}$ long, apically with lateral thickenings (Fig. 29); vesica with a weakly developed cathrema (Fig. 30) but without cornuti (Fig. 26).

Bionomics. Adults fly in February; the typeseries specimens were attracted by light (Figs. 20, 21). Otherwise biology unknown.

Distribution. Known from a single locality, El Naranjo, Valle del Cauca, a rather lush tropical 


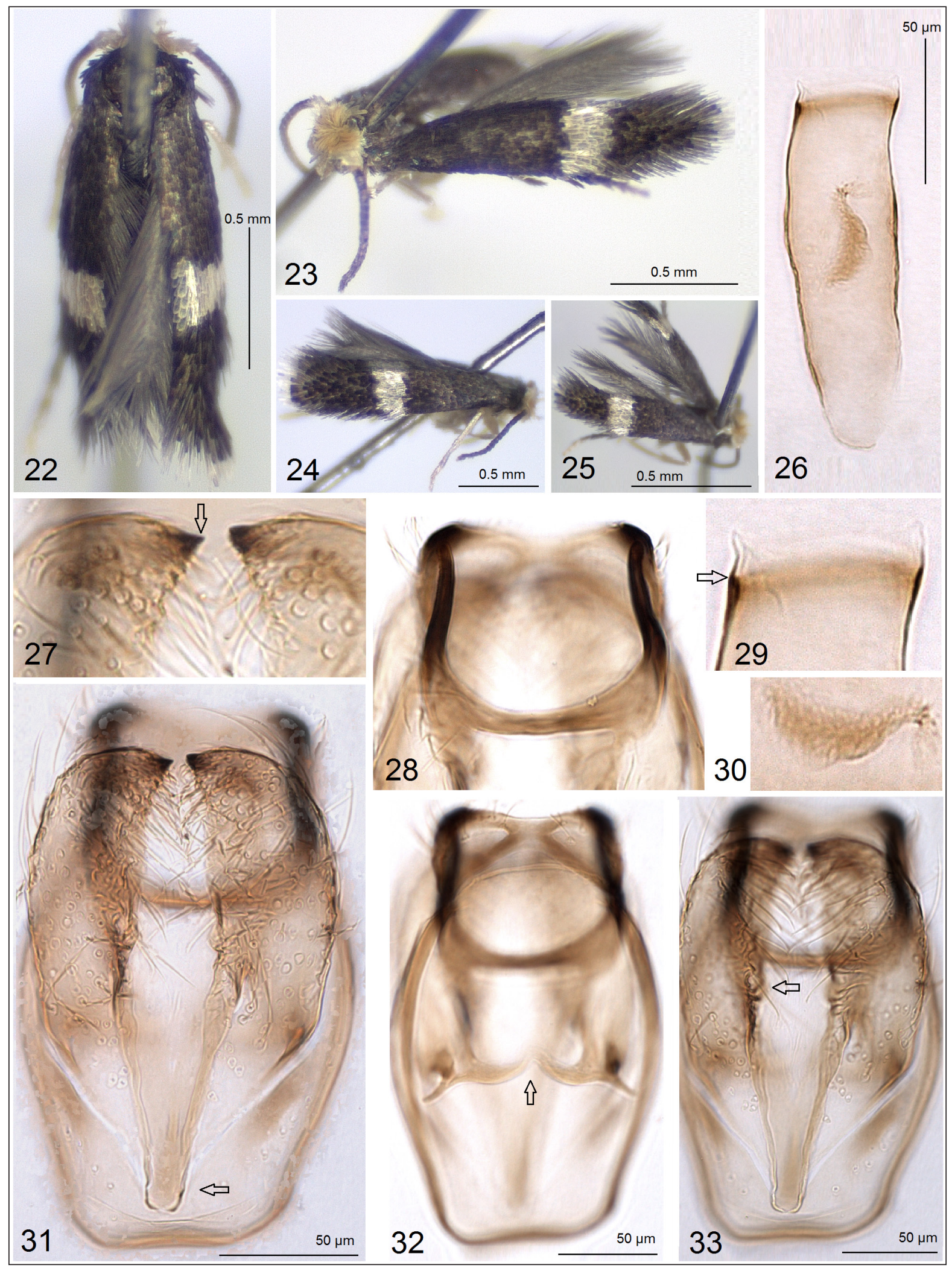

Figs. 22-33. Stigmella foreroi Stonis \& Vargas, sp. nov. 22-25 - male adults, paratype and holotype $(23,25)$; 26 - male genitalia, holotype, slide no. RA1026, phallus; 27, 28 - same, details of genital capsule; 29 - same, apex of phallus; 30 - same, cathrema; 31-33 - same, genital capsule 
habitat on the eastern edge of the Choco biogeographical province in southwestern Colombia at an elevation of about $550 \mathrm{~m}$ (Fig. 17).

Etymology. The species is named after Assoc. Professor Dr. Igor Dimitri Forero Fuentes, coordinator of Biological Collections (Departamento de Biología, Pontificia Universidad Javeriana, Bogotá, Colombia) (also see Acknowledgements).

Remarks. The exact position of this species within Stigmella is uncertain and, therefore, provisional. However, the adult forewing pattern and morphology of the male genitalia of $S$. foreroi are most compatible with that of the representatives of the Stigmella betulicola species group. Therefore, despite the lack of apical clusters of spines on the male phallus, we tentatively atribute the new species to the group of $S$. betulicola species. It is interesting that the $S$. betulicola group is widespread and common in the Palearctics but previously was never reported from the Neotropics.

\section{Summary of the results of the conducted study}

The fieldwork of 2019 in Valle del Cauca, southwestern Colombia, yielded a discovery of ten taxa, all new to the fauna of that country: one species belongs to Opostegidae, seven to Nepticulidae, and two to Tischeriidae.

The study of the Tischeriidae fauna in the Neotropics began in the late nineteenth - early twentieth century, but only during the last two decades the inventory and especially collecting of the Neotropical Tischeriidae has became more purposeful and active (Stonis et al., in press). Prior to our study, no representatives of the Tischeriidae were known from Colombia. During our most recent fieldwork we collected some Tischeriidae specimens, all belonging to the unknown species of Astrotischeria Puplesis \& Diškus (Stonis et al., in press). The discovery also revealed previously unknown host plants from the Asterceae and Malvaceae families. On the basis of the Tischeriidae specimens collected in El Naranjo and Lobo Guerrero (Municipio de Dagua), we identified two new species (described elsewhere, Stonis et al., in press), both of which are characterized by rather unusual morphology of the male and female genitalia. The new species have a strongly developed and thickened dorsal plate of the anellus, which was almost unknown for Astrotischeria, the phallus of one species is unusually small in comparison to other Neotropical tischeriids. Moreover, the female genitalia have many large coils of ductus spermathecae and a unique ovipositor among all Tischeriidae, with greatly reduced primary and particularly secondary ovipositor lobes. It could be possible that at least one of the discovered species has probably an outstanding position in the genus Astrotischeria and may represent a separate species group or even subgenus (Stonis et al., in press).

The Opostegidae family numbers more than 40 species in the Neotropics (Remeikis, 2017). Prior to our study, only one single species of Opostegidae, Pseudopostega pontifex (Meyrick), was known from Colombia (Meyrick, 1915; Stonis et al., 2015). Our studies provided evidence on one more species, which was identified as a new Pseudopostega taxon (it will be described elswhere, Stonis et al., in prep.). It is interesting that this species occurs both in natural habitats (around Cali) and in urban areas of such a megacity as Bogotá.

According to the recent count, the Nepticulidae family of the Neotropical region consisted of more than 225 species, about 150 of which were discovered and described recently (Remeikis, 2017; Stonis, Remeikis, 2018; Stonis, Diškus, 2018; Stonis et al., 2018b, 2018c, 2018d, 2018e). Only a few species possess a broad distribution in the Neotropics, most of the Neotropical species are known from a single locality or restricted area which suppose not only a poor, insufficient study but also a tendency for majority of Nepticulidae ranges to be very limited. The recent collecting, which was conducted on the eastern edge of the Choco biogeographical province, unexpectedly yielded a discovery of species that previously had been known only from Central America. In the current paper, we report on the first discovery of Acalyptris bifidus Puplesis \& Robinson, now known to be occuring 


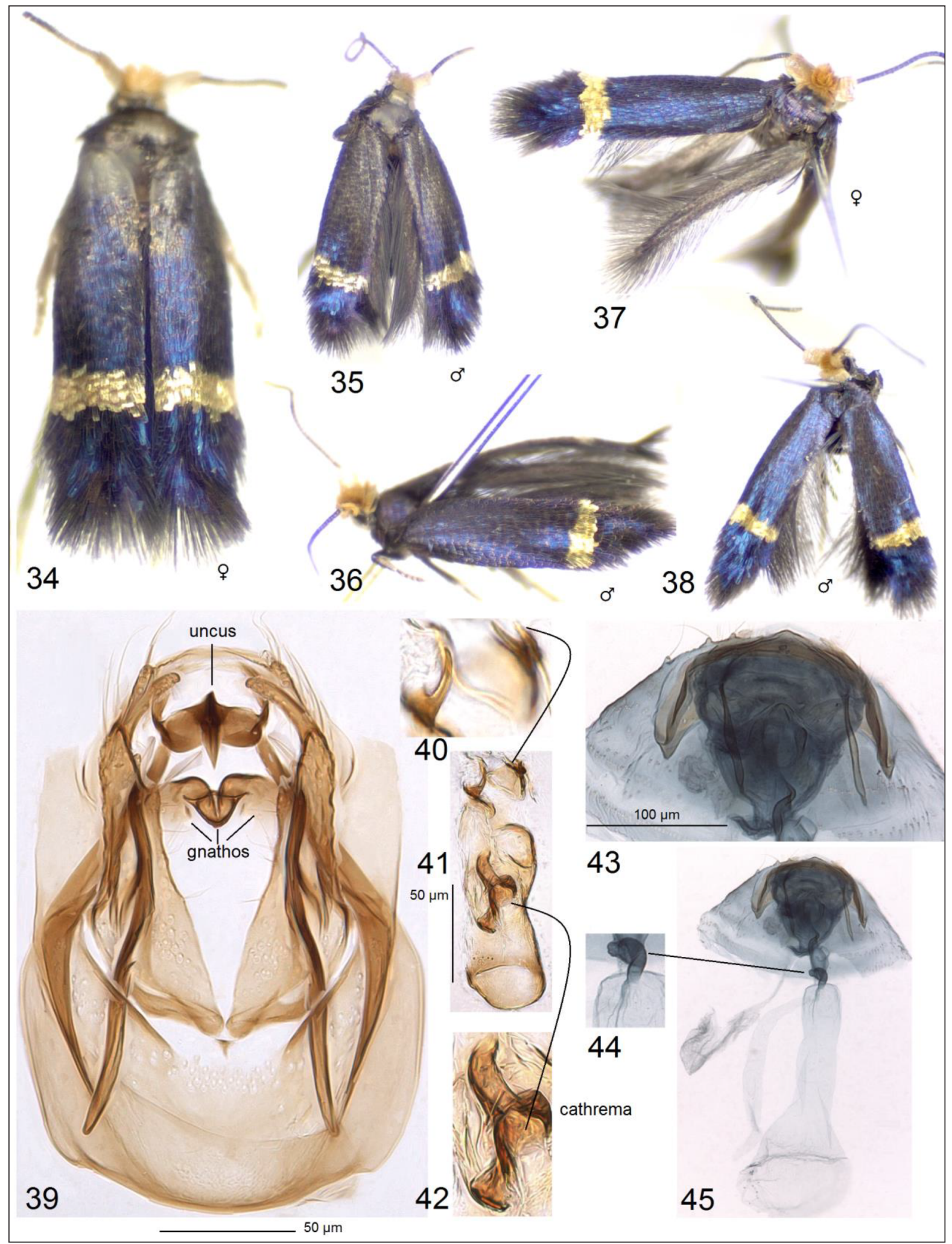

Figs. 34-45. Documentation of Manoneura basidactyla (Davis), collected in Municipio de Dagua, El Naranjo, $550 \mathrm{~m}$, at light, $3^{\circ} 46^{\prime} 46^{\prime \prime} \mathrm{N}, 76^{\circ} 43^{\prime} 63^{\prime \prime} \mathrm{W}, 21-23 . i i .2019$, by J. R. Stonis and S. A. Vargas. 34-38 - adults; 39 - male genitalia, slide no. RA1025, capsule; 40-42 - same, phallus; 43-45 - female genitalia, slide no. RA1024 
from Belize to southwestern Colombia, and Stigmella pruinosa Puplesis \& Robinson, now known to be occurring from southern Mexico and Guatemala to southwestern Colombia. From the morphological point of view, the latter species, S. pruinosa, is very unusual and exhibits an outstanding sexual dimorphism not previously known on such a scale among world's Nepticulidae. Males of S. pruinosa have a set of seven different androconia: white slender scales on forewing (1), black rounded scales on hindwing (2), white slender scales on hindwing (3), white overlapping slender scales on hindwing (4), black overlapping slender scales on hindwing (5), patches of black scales on forewing underside (6), and pale scales on upper side of abdomen (7). Details of this really unususal sexual dimorphism will be documented elsewhere (Stonis et al., submitted).

In the current paper we report the first record of Manoneura basidactyla (Davis), a species originally described from Florida, USA (Davis, 1978, 1979), but later discovered in Belize ( $\mathrm{Pu}-$ plesis and Robinson, 2000), Ecuador (Puplesis et al., 2002a, 2002b; Stonis et al., 2018d), and Guyana (Stonis et al., 2018d). The genus Manoneura is endemic to the Neotropical region and comprised of a few species with purple or coppery-shiny scaling (Stonis et al., 2018d). Here, on the basis of the abundantly collected material, we provide photographic documentation of the morphology of adults (Figs. 34-38), male genitalia, and female genitalia (Figs. 39-45) of the Colombian sample. It is interesting that no significan differences were noticed between the Colombian series and specimens from other countries (molecular studies of the material are in progress).

Among seven Nepticulidae species collected during the fieldwork in Valle del Cauca, four species were recognized as new taxa. Two new species, including the species on Gliricidia sepium, Fabaceae (Fig. 18), belong to the genus Acalyptris Meyrick, the second diverse and widespread Nepticulidae genus in the lowland habitats of the Neotropics (Stonis et al., in preparation). One discovered and probably the most exotic new Nepticulidae species ap- peared to belong to the endemic, Neotropical, recently erected genus Hesperolyra (van Nieukerken et al., 2016). It is important that the new Hesperolyra species was discovered as a pest on guava (Psidium guajava) at least in Municipio de Dagua (Fig. 10). Description of this economically significant and morphologically very unique species along with documentation of damaged leaves of guava will be published elsewhere (Stonis et al., in preparation). This will be the first report on a Nepticulidae pest from Colombia; prior to our research, no Nepticulidae species were known to be associated with cultivated crop plants in the country.

\section{DISCUSSION}

Compiling an inventory of biodiversity is a huge long-lasting task: so far, only a small portion of the world's biodiversity has been studied and described (Puplesis, 2003). The number of already described Tischerioidea and Nepticuloidea species by country is very uneven (Figs. 46, 47). It is not because of the richness of biodiversity but mostly because of the variety in the amount of invested effort, i.e., the research conducted previously. The results of our study, which deal with ten taxa new to the Colombian fauna, include the description of Stigmella foreroi sp. nov. and documentation of Manoneura basidactyla discovered in Colombia for the first time. We also identified new host plants of Nepticulidae and Tischeriidae and registered a pest of guava that appears to be significant from the taxonomic and ecological point of view. By adding ten new species to the fauna, we more than doubled the previously known number of Nepticuloidae and Tischerioidea. Nevertheless, the Colombian fauna of nepticuloids and tischerioids is still at the intial stage of study.

We hope that this survey of the newlycollected material will stimulate further studies in this much-neglected country in respect to Nepticuloidea and Tischerioidea and will build a more detailed account of the diversity of the Colombian leaf-mining insects. There is so much work for researchers. 


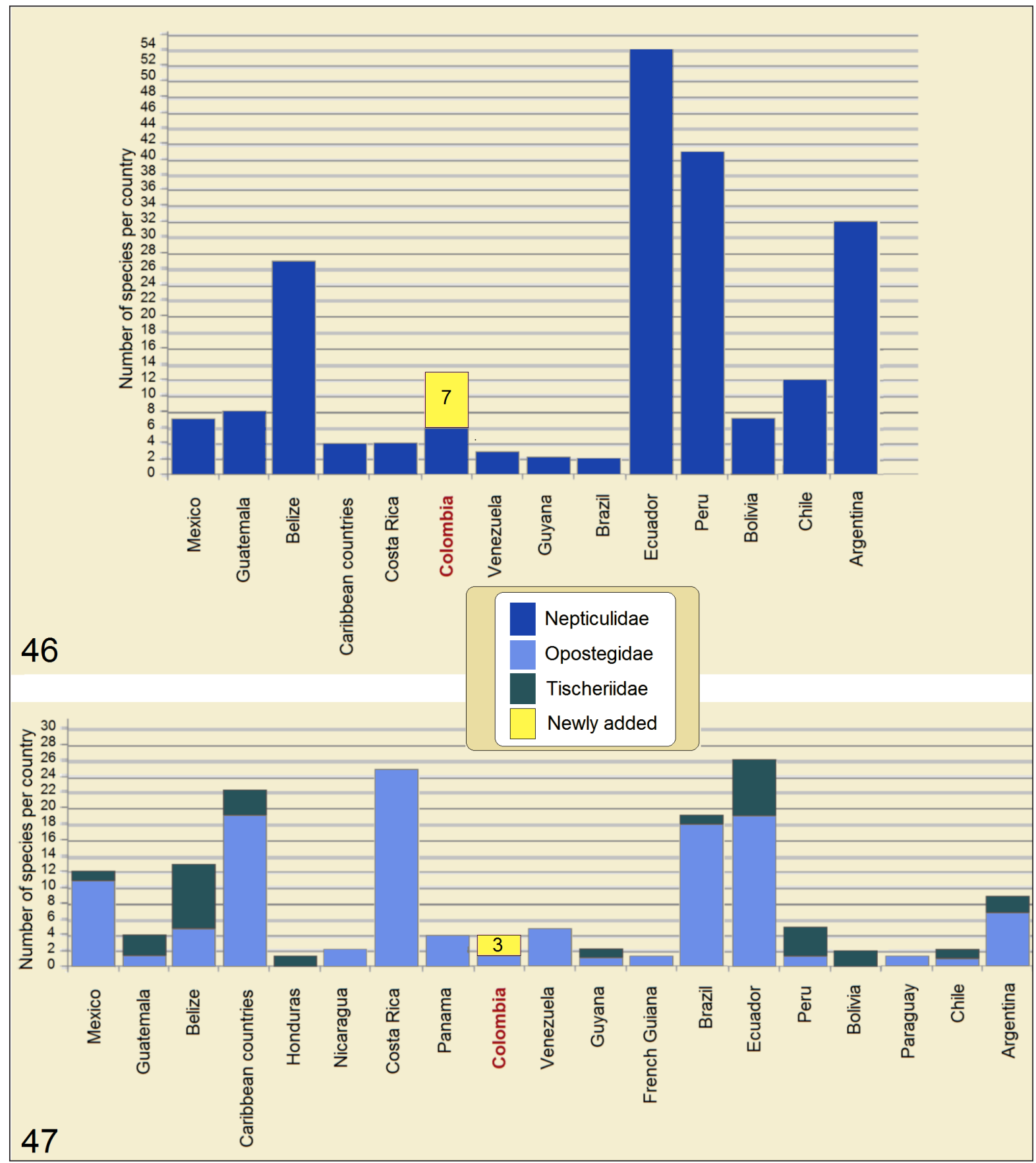

Figs. 46, 47. The number of described species by country. 46 - Nepticulidae; 47 - Opostegidae and Tischeriidae (Note: Neotropical countries not showed above have no published records on nepticuloids and tischerioids)

\section{ACKNOWLEDGEMENTS}

The authors of the present paper are deeply indebted to Professor Dr. Igor Dimitri Forero Fuentes, coordinator of Biological Collections (Departamento de Biología, Pontificia Universi- dad Javeriana, Bogotá, Colombia) for the stimulus, scientific collaboration, his generous support during the course of our studies on the Colombian Nepticuloidea and Tischerioidea, and also for facilitating a permit to collect study material in the country. For the collecting permit, 
we also thank Autoridad Nacional de Licencias Ambientales, Bogotá, Colombia. We are indebted to our field assistant Franklin Jesus Galindo Meza (Cali) for his generous help during our fieldwork in Valle del Cauca. For the effort to identify the host plants, we thank botanist Esteban Moreno (Jardín Botánico de Bogotá José Celestino Mutis, Bogotá Colombia) and Professor Liliana Katinas (División Plantas Vasculares, Museo de La Plata, Argentina). We would like to express our gratitude to Assoc. Professor Dr. Arūnas Diškus (Vytautas Magnus University, Vilnius, Lithuania), a member of the Biosystematics Research Group, for permanent and inspiring scientific cooperation and the photograph provided in Fig. 3. This research was partially funded by a grant (S-MIP-19-30) from the Research Council of Lithuania.

Received 8 May 2019

Accepted 17 May 2019

\section{References}

1. Colombia [Internet]. 2015. Wildlife Conservation Society. Available from: http://www.wcs. org/where-we-work/latin-america/colombia. aspx [retrieved 30 Jun 2019]

2. Colombia - Country Profile [Internet]. 2015. Convention on Biological Diversity. Available from: https://www.cbd.int/countries/ profile/default.shtml? country $=$ co $\quad$ [retrieved 30 Jun 2019]

3. Davis DR. New leaf-mining moths of the family Nepticulidae from Florida. Fla Entomol 1978; 61(4): 209-24.

4. Davis DR. Manoneura, a new name to replace the generic homonym Oligoneura Davis (Lepidoptera: Nepticulidae). Fla Entomol 1979; 62(3): 276.

5. Diškus A, Stonis JR. Leaf-mining insects of Lithuania. The Nepticulidae (Lepidoptera): taxonomy, chorological composition and trophic relationships. Kaunas: Lututè Publishers; 2012. 220 p. Lithuanian.
6. Johansson R, Nielsen ES, van Nieukerken EJ, Gustafsson B. The Nepticulidae and Opostegidae (Lepidoptera) of North West Europe. Fauna Entomol Scand 1990; 23(1/2): 1-739.

7. Kuznetzov VI, Puplesis R. Sem. Nepticulidae (Stigmellidae) - moli-malyutki. In: Kuznetzov, VI, editor. Nasekomye i kleshchi - vrediteli sel'skokhozyaistvennykh kul'tur. Cheshuekrylye [Insects and mites - pests of agricultural plants. Lepidoptera]. St. Petersburg: Nauka Publishers 1994; 3(1): 12-23. Russian.

8. Meyrick E. Descriptions of South American Micro-Lepidoptera. Trans Entomol Soc Lond 1915; 48(2): 201-56.

9. Morrone JJ. Biogeographical regionalisation of the Neotropical region. Zootaxa 2014; 3782(1): $1-110$.

10. Morrone JJ. Biogeographical regionalisation of the Andean region. Zootaxa 2015; 3936(2): 207-36.

11. Nieukerken EJ van, Doorenweerd C, Nishida K, Snyers C. New taxa, including three new genera show uniqueness of Neotropical Nepticulidae (Lepidoptera). ZooKeys 2016; 628: 1-63.

12. Puplesis R. Biodiversity. An introduction to global animal and plant diversity Kaunas: Lututè Publishers, 2003: 154 p. Lithuanian.

13. Puplesis R, Diškus A. The Nepticuloidea \& Tischerioidea (Lepidoptera) - a global review, with strategic regional revisions. Kaunas: Lututè Publishers; 2003. 512 p.

14. Puplesis R, Diškus A, Robinson GS. New Neotropical Nepticulidae (Lepidoptera) from the western Amazonian rainforest and the Andes of Ecuador. Bull Nat Hist Mus Entomol 2002a; 71(1): 19-58.

15. Puplesis R, Diškus A, Robinson GS, Onore G. A review and checklist of the Neotropical Nepticulidae (Lepidoptera). Bull Nat Hist Mus Entomol. 2002b; 71(1): 59-76.

16. Puplesis R, Robinson GS. A review of the Central and South American Nepticulidae (Lepidoptera) with special reference to Belize. Bull Nat Hist Mus Entomol 2000; 69(1): 3-114. 
17. Remeikis A. Fauna and trophic relationships of the Middle and South American Nepticuloidea (Lepidoptera: Nepticulidae, Opostegidae) [summary of doctoral dissertation]. Vilnius: Vilnius University and Nature Research Centre; 2017. 71 p.

18. Stonis JR. Kodèl taksonominiai biologinès ìvairovès tyrimai svarbūs Lietuvai? Mokslo Lietuva, 2010; 8: 1-6. Lithuanian.

19. Stonis JR, Diškus A. Acalyptris amazonensis sp. nov.: documentation of another leafmining species supplementing the unique but disputable A. latipennata group (Lepidoptera: Nepticulidae). Biologija 2018; 64(3): 191-202.

20. Stonis JR, Diškus A., Carvalho Filho F, Lewis OT. American Asteraceae-feeding Astrotischeria species with a highly modified, threelobed valva in the male genitalia (Lepidoptera, Tischeriidae). Zootaxa 2018a; 4469(1): 1-69.

21. Stonis JR, Diškus A, Katinas L, Solis MA. Asteraceae: host to the greatest diversity of leaf-mining Nepticulidae (Lepidoptera) in South America? Proc Entomol Soc Wash 2018b; 120(4): 856-902.

22. Stonis JR, Diškus A, Solis MA. Two new Fabaceae-feeding Nepticulidae (Lepidoptera) from the Western Hemisphere, including a potential pest of the economically important Centrolobium Mart. ex Benth. Proceedings of the Entomological Society of Washington 2018c; 120(4): 842-55.

23. Stonis JR, Diškus A, Remeikis A, Navickaitė A. Study methods of Nepticulidae: micro-mounts of genitalia structures. In: Stonis JR, Hill SR, Diškus A, Auškalnis T, editors. Selected abstracts and papers of the First Baltic International Conference on Field Entomology and Faunistics. Vilnius: Edukologija Publishers; 2014. p. 32-5.

24. Stonis JR, Diškus A, Remeikis A, Solis MA. The American Brachinepticula gen. nov. and
Manoneura Davis (Nepticulidae): a new generic concept based on a reinforced cathrema in the phallus. Biologija 2018d; 64(2): 99-128.

25. Stonis JR, Diškus A., Remeikis A., Solis MA. A Gondwanan concept of Simplimorpha Scoble (sensu lato): a step toward clarity in the generic diagnostics of global Nepticulidae (Lepidoptera). Zootaxa 2018e; 4521(2): 151-82.

26. Stonis JR, Remeikis A. Odd species of Nepticulidae (Lepidoptera) from the American rainforest and southern Andes. Zootaxa 2018; 4392(3): 458-68.

27. Stonis JR, Diškus A, Remeikis A, Davis DR, Solis MA, Cumbicus Torres N. The first record of Baccharis L. (Asteraceae) as a host-plant genus for Nepticulidae (Lepidoptera), with description of new Stigmella species from South America. Zootaxa 2016a; 4136(1): 101-28.

28. Stonis JR, Remeikis A, Diškus A, Forero D, Cumbicus Torres N. A report on Lamiaceae-feeding Nepticulidae (Lepidoptera) from South America. Zootaxa 2017a; 4338(1): 128-40.

29. Stonis JR, Remeikis A, Diškus A, Gerulaitis V. The Ando-Patagonian Stigmella magnispinella group (Lepidoptera, Nepticulidae) with description of new species from Ecuador, Peru and Argentina. Zootaxa 2016b; 4200(4): 561-79.

30. Stonis JR, Remeikis A, Diškus A, Megoran N. New species of leaf-mining Nepticulidae (Lepidoptera) from the Neotropical and AndoPatagonian regions, with new data on hostplants. Zootaxa 2017b; 4272(1): 1-39.

31. Stonis JR, Remeikis A, Gerulaitis V, Forero D. An embarrassing situation requiring urgent action: Colombia, a country of extraordinary biodiversity, still counts only few species of Nepticuloidea (Insecta, Lepidoptera). Biologija 2015; 61(3-4): 123-29. 
Jonas Rimantas Stonis, Andrius Remeikis, Sergio Andreas Vargas

KOLUMBIJOS GAUBTAGALVIAI (NEPTICU-

LOIDAE) IR ŠERIUOTAŪSIAI (TISCHERIO-

IDEA): MAŽAS ŽINGSNELIS LINK GERESNIO

ŠIŲ ORGANIZMŲ TAKSONOMINĖS İVAIROVĖS SUVOKIMO

\section{Santrauka}

Kolumbijoje, pasižyminčioje išskirtinai didele biologine ịvairove, iki šiol išaiškinta nedaug augalus minuojančių Nepticuloidea ir Tischerioidea (Insecta, Lepidoptera) rūšių. Šiame straipsnyje pirmą kartą publikuojami apibendrinti duomenys apie gaubtagalvius (Nepticulidae ir Opostegidae) ir šeriuotaūsius (Tischerioidea: Tischeriidae), aptiktus 2019 m. ekspedicinių lauko darbų metu pietvakarių Kolumbijoje. Aprašoma mokslui nauja rūšis - Stigmella foreroi, priklausanti Nepticulidae šeimai. Vienas iš šio straipsnio tikslų - atkreipti dèmesi $\mathfrak{i}$ vis dar menką Kolumbijos Nepticuloidea ir Tischerioidea ištyrimą bei paskatinti šios faunos tyrimus.

Raktažodžiai: fauna, Kolumbija, naujos rūšys, augalų minuotojai, Nepticulidae, mažieji gaubtagalviai, Opostegidae, baltieji gaubtagalviai, Tischeriidae, šeriuotaūsiai 